University of Wollongong

Research Online

Faculty of Engineering - Papers (Archive)

Faculty of Engineering and Information

Sciences

$1-1-2011$

\title{
Evaluating waste concrete for the treatment of acid sulphate soil groundwater from coastal floodplains
}

\author{
Gyanendra Regmi \\ University of Wollongong, gr524@uowmail.edu.au \\ Buddhima Indraratna \\ University of Wollongong, indra@uow.edu.au \\ Long Nghiem \\ University of Wollongong, longn@uow.edu.au \\ Laura Banasiak \\ University of Wollongong, Ibanasia@uow.edu.au
}

Follow this and additional works at: https://ro.uow.edu.au/engpapers

Part of the Engineering Commons

https://ro.uow.edu.au/engpapers/919

\section{Recommended Citation}

Regmi, Gyanendra; Indraratna, Buddhima; Nghiem, Long; and Banasiak, Laura: Evaluating waste concrete for the treatment of acid sulphate soil groundwater from coastal floodplains 2011, 126-132.

https://ro.uow.edu.au/engpapers/919

Research Online is the open access institutional repository for the University of Wollongong. For further information contact the UOW Library: research-pubs@uow.edu.au 


\title{
Evaluating waste concrete for the treatment of acid sulphate soil groundwater from coastal floodplains
}

\author{
Gyanendra Regmi, Buddhima Indraratna*, Long Duc Nghiem, Laura Banasiak \\ School of Civil, Mining and Environmental Engineering, University of Wollongong, NSW 2522, Australia \\ Tel. +61 (2) 4221 3046; Fax+61 (2) 42213238; email: indra@uow.edu.au
}

Received 1 August 2010; Accepted in revised form 30 December 2010

\begin{abstract}
AB S T R AC T
The treatment of acidic groundwater generated from acid sulphate soil (ASS) terrain is a challenging environmental issue in coastal floodplains of Australia. In this study, a laboratory column experiment was conducted to assess the performance of waste concrete for treating the acidic groundwater leachate from ASS terrain of the Shoalhaven region of NSW. The groundwater was highly acidic ( $\mathrm{pH}$ of 2.5-3.5) and contained elevated concentrations of iron (10-90 mg/L) and aluminium $(30-45 \mathrm{mg} / \mathrm{L})$. Passage of the acidic groundwater through the column filled with waste concrete resulted in a significant improvement in water quality. Reduction in the concentration of iron and aluminium to below detection limits and improvement of the $\mathrm{pH}$ from acidic to near-neutral $\mathrm{pH}$ 6-8) were observed, along with a significant release of alkalinity over a six month period under controlled laboratory conditions. The results show that the working lifetime of waste concrete as the reactive media was governed primarily by the precipitation of secondary minerals despite the high acid neutralisation capacity of the waste concrete material.
\end{abstract}

Keywords: Acid sulphate soil; Contaminated groundwater; Column test; Groundwater remediation; Waste concrete

\section{Introduction}

Acid sulphate soils (ASS) have been identified since the early 1960s as a considerable environmental, economic and social problem that affects over three million hectares of coastal floodplains and estuaries in Australia $[1,2]$. Under reducing conditions, ASS remains chemically inert. When the water table decreases exposing sulphidic minerals such as pyrite to air, oxidation of these mineral occurs generating acidic drainage that is high in potentially harmful metals such as iron (Fe) and aluminium (Al) [3]. Large-scale artificial drainage in low-lying coastal

\footnotetext{
* Corresponding author.
}

areas of Australia has increased the distribution, magnitude and frequency of acid generation, which in turn has increased the rate of estuarine acidification by many orders of magnitude greater than that which might have occurred under natural drought/flood cycles [4]. Severe and periodic discharges of acidic water corrode steel and concrete infrastructure, clog waterways with Fe flocculates, kill aquatic ecology and produce large acid scalds that render land unsuitable for agricultural purposes [5].

Engineering solutions such as weirs and modified two-way floodgates have been installed near Broughton $\mathrm{Ck}$, southeastern New South Wales, Australia to reduce the amount of acid generated through abiotic and biotic oxidation of pyrite by elevating the water table and to 
buffer acidity before it is released into the estuarine environment [6,7]. However, these mitigation measures are not feasible in very low-lying areas due to the risk of flooding during significant rainfall events. Biological oxidation of pyrite under submerged conditions can also still prevail if the organic content and sulphidic constituents of the soils are high. Thus, permeable reactive barriers (PRBs) have been identified as a potential remediation technique in these low-lying areas. APRB is an engineered treatment zone consisting of a trench filled with reactive materials placed in the subsurface in order to remediate contaminated fluids as they flow through it. To date, PRBs have been proved as an efficient remedial method for groundwater contaminated with chlorinated volatile organic compounds [8], radionuclides [9], heavy metals [10] and acid mine drainage [11]. The use of PRBs to treat ASS acidic groundwater has been recently demonstrated in Australia [12]. A pilot subsurface alkaline PRB using waste concrete aggregate to neutralise acidic groundwater due to ASS was installed at a farm in Bomaderry, southeastern NSW in 2006. Although a slow decrease in performance was observed over three years of operation [13], the PRB maintained near neutral $\mathrm{pH}$ with complete removal of $\mathrm{Fe}$ and $\mathrm{Al}$ from the groundwater [14].

The objective of this study was to assess the performance of waste concrete obtained from a construction waste depot in neutralising acidity due to ASS groundwater and removing dissolved metal cations such as Fe and Al under varying flow conditions. In order to achieve this goal the performance of the waste concrete as reactive media was evaluated in a laboratory column experiment using real ASS groundwater garnered from the pilot PRB field site. The influence of chemical armouring and physical clogging of the waste concrete due to the precipitation of Fe and $\mathrm{Al}$ was studied.

\section{Materials and method}

\subsection{Materials}

The waste concrete used for the column experiment was collected from a construction waste depot, and was the same batch of concrete used in the pilot PRB installed in ASS terrain $[13,14]$. Large pieces of the waste concrete were crushed to a smaller size suitable for the column. The particle size distribution of heterogeneous crushed concrete ranged from $1.18 \mathrm{~mm}$ to $9 \mathrm{~mm}$ with an effective mean diameter $\left(\mathrm{d}_{50}\right)$ of $5.2 \mathrm{~mm}$ similar in character to medium-coarse gravel. Accurate identification of the composition of hydration products of the concrete was difficult due to the physical, chemical and mechanical changes in solidified materials in cementitious systems. In addition, accurate quantification of the minerals was a challenging task due to the heterogeneity of the concrete particles. Therefore, small samples of the concrete were ground in a mill ball to a fine powder for further mineralogical analysis. X-ray diffraction (XRD) was carried out to identify the major mineral phases present in the waste concrete before studying its acid neutralisation behaviour. The detailed elementary composition of the waste concrete was presented in Regmi et al. [13].

\subsection{Groundwater sampling}

Groundwater was collected on a monthly basis from sampling wells at an ASS affected farm in Bomaderry, southeastern NSW, Australia. Chemical composition of the acidic groundwater passed through the column at different time intervals is shown in Table 1. The groundwater was acidic ( $\mathrm{pH}$ in range of 2.5-3.5) with high concentrations of Fe and Al.

\subsection{Experimental procedure}

A laboratory column test was conducted to assess the performance of waste concrete for the neutralisation of and the removal of metals from the acidic groundwater. A $5 \mathrm{~cm}$ internal diameter, $65 \mathrm{~cm}$ long acrylic column was packed with the waste concrete. The concrete was placed within a zone approximately $50 \mathrm{~cm}$ in length in the column bounded by sand layers approximately $10 \mathrm{~cm}$ and $5 \mathrm{~cm}$ in thickness at the base and the top of the column, respectively following the procedures in [13] (see Regmi et al. [13] for further details of the column configuration). The average total porosity was 0.52 (total void volume was $515 \mathrm{~cm}^{3}$ ). The porosity was determined by dividing the total void volume by the volume of the column while the total void volume was determined by weighing the column dry and fully saturated.

A Masterflux peristaltic pump was used to inject the influent continuously through the column at a constant flow rate of $1.15 \mathrm{~mL} / \mathrm{min}$ for 260 days at room temperature $\left(23-25^{\circ} \mathrm{C}\right)$. The column experiment was conducted at a higher flow rate than the groundwater flow rate in the field to illustrate the acid neutralisation behaviour of the material in a short time period in the laboratory. Effluent samples were collected from five sampling ports at intervals of 10, 20, 30, 50 and $55 \mathrm{~cm}$ (outlet) along the length of the column. Measurements of $\mathrm{pH}$, oxidation reduction potential (ORP), acidity and alkalinity were determined immediately after sampling. Samples were filtered through $0.45 \mu \mathrm{m}$ cellulose acetate filter paper, and both acidified and non-acidified samples were collected and stored in a refrigerator at $4^{\circ} \mathrm{C}$ prior to analysis. Major cations $\left(\mathrm{Na}^{+}, \mathrm{K}^{+}, \mathrm{Ca}^{2+}, \mathrm{Mg}^{2+}\right.$, total $\mathrm{Fe}$ and $\left.\mathrm{Al}^{3+}\right)$ were determined using inductively coupled plasma optical emission spectroscopy (ICP-OES) and atomic absorbance spectroscopy (AAS). Anions $\left(\mathrm{SO}_{4}^{2-}\right.$ and $\left.\mathrm{Cl}^{-}\right)$were measured using ion chromatography. All chemical analyses were performed according to the standard method for water and wastewater examination [15]. Acid Neutralization Capacity (ANC) of the concrete was determined 
Table 1

Composition of feed water quality used in column experiment

\begin{tabular}{llllllllllllll}
\hline $\begin{array}{l}\text { Input } \\
\text { solution }\end{array}$ & $\begin{array}{l}\text { Duration } \\
(\mathrm{d})\end{array}$ & $\mathrm{pH}$ & $\begin{array}{l}\mathrm{EC} \\
(\mu \mathrm{S} / \mathrm{cm})\end{array}$ & $\begin{array}{l}\mathrm{Eh} \\
(\mathrm{mV})\end{array}$ & $\begin{array}{l}\text { Acidity } \\
\mathrm{mg} / \mathrm{L} \\
\mathrm{as} \mathrm{CaCO}\end{array}$ & $\mathrm{Na}^{+}$ & $\mathrm{Ca}^{2+}$ & $\mathrm{K}^{+}$ & $\begin{array}{l}\mathrm{Mg}^{2+} \\
(\mathrm{mg} / \mathrm{L})\end{array}$ & $\begin{array}{l}\mathrm{Total} \mathrm{Fe}^{3+} \\
\mathrm{Al}^{3+}\end{array}$ & $\mathrm{Cl}^{-}$ & $\mathrm{SO}_{4}^{2-}$ \\
\hline Feed 1 & $0-35$ & 3.4 & 4100 & 520 & 360 & 364 & 155 & 39 & 86 & 6.9 & 44.2 & 606 & 1092 \\
Feed 2 & $35-70$ & 3.5 & 4100 & 520 & 315 & 358 & 155 & 38 & 84 & 7.2 & 44.0 & 606 & 1041 \\
Feed 3 & $70-133$ & 3.2 & 3950 & 525 & 315 & 352 & 136 & 39 & 83 & 7.0 & 45.0 & 559 & 993 \\
Feed 4 & $133-165$ & 3.01 & 4080 & 525 & 525 & 375 & 157 & 37 & 157 & 89.4 & 30.4 & 604 & 1291 \\
Feed 5 & $165-176$ & 3.13 & 4080 & 527 & 360 & 375 & 157 & 40 & 97 & 16.4 & 28.6 & 762 & 1318 \\
Feed 6 & $176-196$ & 2.57 & 4220 & 505 & 530 & 514 & 147 & 40 & 160 & 78.3 & 32.9 & 781 & 1318 \\
Feed 7 & $196-230$ & 2.97 & 4220 & 500 & 405 & 293 & 143 & 40 & 129 & 20.0 & 42.7 & 609 & 1134 \\
Feed 8 & $230-253$ & 2.76 & 4060 & 526 & 405 & 248 & 143 & 40 & 129 & 52.0 & 42.7 & 491 & 1134 \\
Feed 9 & $253-260$ & 2.76 & 4060 & 526 & 405 & 384 & 143 & 40 & 129 & 52.0 & 42.7 & 801 & 1134 \\
\hline
\end{tabular}

Acidity was calculated corresponding to $\mathrm{pH} 7$

following the Acid Sulphate Soils Laboratory Method Guidelines [16].

\section{Results and discussion}

\subsection{X-ray diffraction/mineral characterisation}

The results of the XRD analysis of the concrete are presented in Fig. 1. Significant peaks of quartz and Ca-bearing minerals were identified, indicating quartz, feldspar (anorthite, albite, etrringite etc.) and calcite as the predominant mineral phases in the waste concrete. The peak of Ca-bearing minerals are attributed to the cement whereas the peak of quartz is attributed to the sand and aggregates. Table 2 shows the XRD quantitative analysis, confirming that different phases of feldspar were high compared with portlandite. Although a significant amount of quartz was observed in the concrete, it was chemically inert in the acid neutralisation reaction.

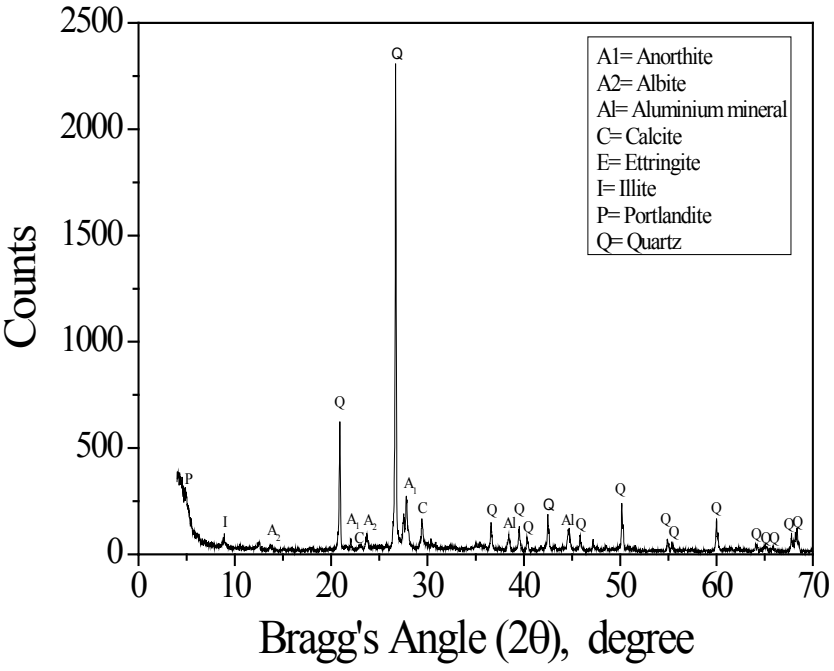

Fig. 1. X-ray diffraction (XRD) analysis of the crushed concrete powder.

Table 2

Mineralogical analysis (XRD) of the waste concrete used in the column experiment

\begin{tabular}{lll}
\hline Minerals & Formula & Percentage by weight $(\%)$ \\
\hline Quartz & $\mathrm{SiO}_{2}$ & 64.4 \\
Portlandite & $\mathrm{Ca}(\mathrm{OH})_{2}$ & 0.3 \\
Anorthite* & $\mathrm{CaAl} \mathrm{Si}_{2} \mathrm{O}_{8}$ & 16.8 \\
Albite $(\text { low })^{*}$ & $\mathrm{NaAlSi}_{3}$ & 8.4 \\
Illite 1 & $\left(\mathrm{~K}, \mathrm{H}_{3} \mathrm{O}\right)(\mathrm{Al}, \mathrm{Mg}, \mathrm{Fe})_{2}(\mathrm{Si}, \mathrm{Al})_{4} \mathrm{O}_{10}\left[(\mathrm{OH})_{2^{\prime}}\left(\mathrm{H}_{2} \mathrm{O}\right)\right]$ & 0.3 \\
Ettringite* & $(\mathrm{CaO})_{6}\left(\mathrm{Al}_{2} \mathrm{O}_{3}\right)\left(\mathrm{SO}_{3}\right)_{3} \cdot 32 \mathrm{H}_{2} \mathrm{O}$ & 4.8 \\
Calcite & $\mathrm{CaCO}{ }_{3}$ & 4.4 \\
Muscovite & $(\mathrm{KF})_{2}\left(\mathrm{Al}_{2} \mathrm{O}_{3}\right)_{3}\left(\mathrm{SiO}_{2}\right)_{6}\left(\mathrm{H}_{2} \mathrm{O}\right)$ & 5.0 \\
Total & & 100 \\
\hline
\end{tabular}

\footnotetext{
* Feldspar mineral
} 


\subsection{Water quality parameters}

The high initial effluent $\mathrm{pH}(10.8-8.0)$, as shown in Fig. 2, was due to the dissolution of soluble minerals portlandite and ettringite from the concrete and the subsequent release of hydroxyl and carbonate alkalinity. Initial $\mathrm{pH}$ of 10.8 could not be maintained for a long time period due to the negligible amount of portlandite in the concrete (Table 2). Maintenance of the $\mathrm{pH}$ above 8 for a few days was attributed to ettringite, which undergoes rapid dissolution between $\mathrm{pH} 10.7$ and 9.5. ÁlvarezAyuso and Nugteren [17] and Golab et al. [18] suggested that the theoretical equilibrium $\mathrm{pH}$ for portlandite and ettringite are 12.1 and 10.7, respectively. The effluent $\mathrm{pH}$ decreased rapidly from 10.8 to 8.0 within 50 days, after which two long plateaus were observed. A near-neutral plateau ( $\mathrm{pH} 8.0$ to 7.5) continued until day 135 followed by a slow decrease to 6.0 at day 190. The $\mathrm{pH}$ then dropped abruptly reaching the next plateau at $\mathrm{pH} 4.2-4.0$.

The total alkalinity of the effluent is governed by the release of alkaline materials from the recycled concrete and the initial chemistry of the groundwater. At the beginning of the column experiment, the total alkalinity decreased from 70 to $40 \mathrm{mg} / \mathrm{L}$ within the first 40 days as the hydroxyl and carbonate alkalinity generated by trace amounts of alkaline portlandite and ettringite was depleted (Fig. 3). Correspondingly, the effluent $\mathrm{pH}$ decreased rapidly until the generation of bicarbonate alkalinity (a strong buffer) in the column by anorthite and calcite, whereby a long plateau ( $\mathrm{pH}$ 7.9-7.5) was observed until day 135 (Fig. 2). In fact, from day 40 onward, as bicarbonate alkalinity was released, the total alkalinity increased and reached a peak value of $140 \mathrm{mg} / \mathrm{L}\left(\right.$ as $\left.\mathrm{CaCO}_{3}\right)$ at approximately 85 days, followed by a gradual decrease. Fast depletion of alkalinity after 180 days indicates that a decrease in efficiency of the reactive material occurred from this point. Complete depletion of alkalinity at day 190 was accompanied by a sharp decline in $\mathrm{pH}$ to about pH 4 and an increase in ORP (Figs. 2-4) indicating that the column system was not buffered. The $\mathrm{pH}$ remained stable until equilibrium with the most soluble Al hydroxide mineral was attained. In good agreement, Jurjovec et al. [19] and Regmi et al. [20] observed a similar stable pH behaviour during the generation of carbonate/bicarbonate alkalinity followed by a rapid drop in $\mathrm{pH}$ after the total depletion of these carbonate minerals in acid mine drainage and ASS, respectively. In addition, Jurjovec et al. [19] reported the plateau of $\mathrm{pH}$ due to equilibrium of the effluent water with respect to gibbsite $\left(\mathrm{Al}(\mathrm{OH})_{3}\right)$ at $\mathrm{pH} 4.0$ in the remediation of acid mine drainage.

The initial ORP of the effluent was low $(100 \mathrm{mV})$ and remained between $200-250 \mathrm{mV}$ until a near neutral $\mathrm{pH}$ was maintained (Fig. 4); indicating poor oxidation conditions. Drops in $\mathrm{pH}$ corresponded to rapid increases in ORP in the bottom part of the column (Fig. 2 and Fig. 4) at $27,37,61,141$ and 190 days for sampling ports at distances

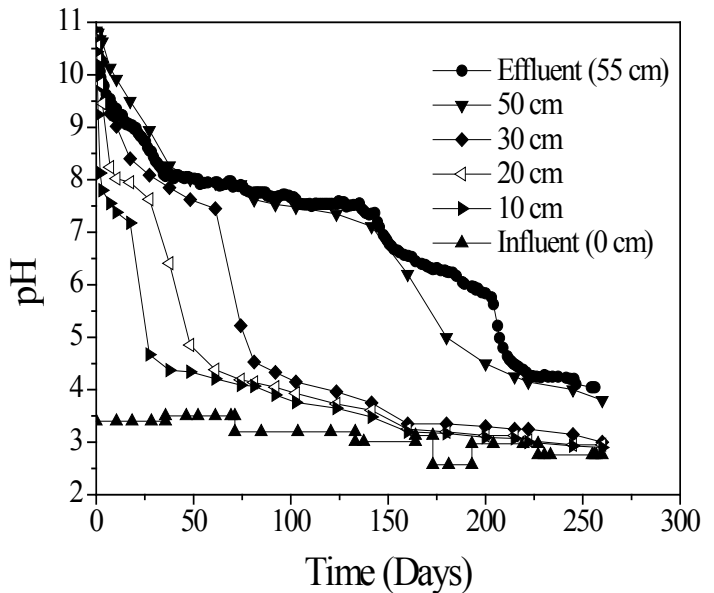

Fig. 2. $\mathrm{pH}$ as a function of time at different sampling ports from the interface of the bottom sand and concrete layer.

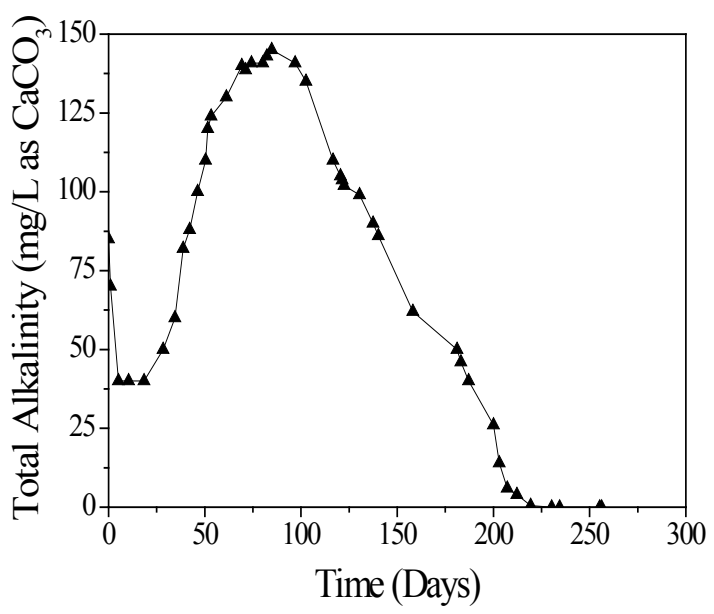

Fig. 3. Effluent total alkalinity $\left(\mathrm{mg} / \mathrm{L}\right.$ as $\left.\mathrm{CaCO}_{3}\right)$ as a function of time.

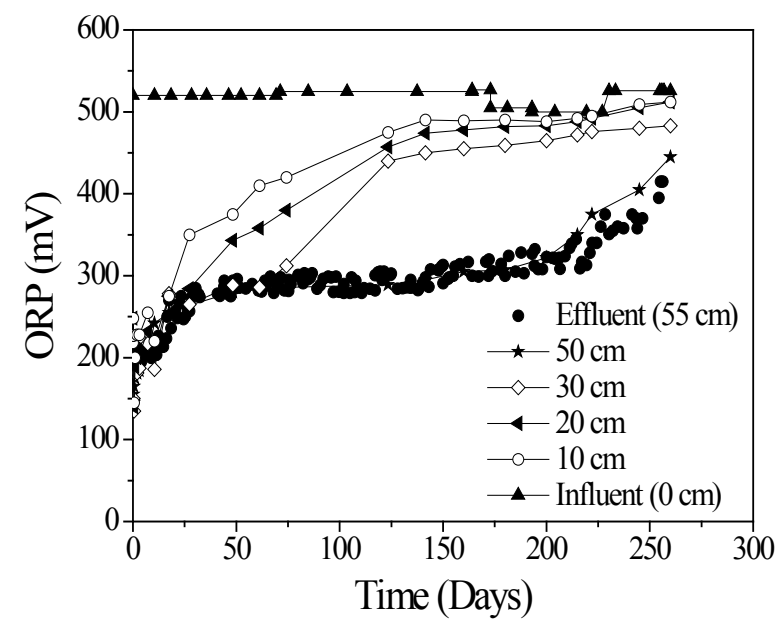

Fig. 4. Oxidation reduction potential (ORP) as a function of time at different sampling ports from the interface of the bottom sand and concrete layer. 
of 10, 20, 30, 50 and $55 \mathrm{~cm}$, respectively. This indicates fast depletion of alkalinity at the advancing acid front, which was supported by the growth of visible white and orange precipitates upwards from the bottom of the column. However, the alkalinity generated in the upper part of the column (Fig. 3) maintained the effluent $\mathrm{pH}$ plateau from the outlet port at near neutral with continuous release of $\mathrm{Ca}$ (Fig. 5) for a longer period. These results illustrate that the waste concrete neutralised the acidic water for a long period under a high flow rate despite the considerable amount of acidic groundwater passed through the column, thus proving its high potential for neutralising contaminated groundwater from ASS under variable environmental conditions.

\subsection{Groundwater chemistry}

Acidic groundwater was regularly collected from the PRB site to run through the column and as a result ion concentrations in the influent were heterogeneous over time and varied depending on the field conditions and sampling period. Peaks in Fe and $\mathrm{Al}$ concentrations (Figs. 6-7) resulted from pyrite oxidation during drought periods and subsequent mobilization from soil during rain events [7]. Observed sudden changes in effluent ions concentrations in short interval of time correspond to changes in the influent ions concentrations caused by the stored groundwater collected at different times.

Despite variations in influent $\mathrm{Fe}$ and $\mathrm{Al}$ concentrations, the high $\mathrm{pH}$ maintained in the column until the presence of bicarbonate alkalinity favoured $\mathrm{Fe}$ and $\mathrm{Al}$ precipitation (Fig. 6 and Fig. 7). The Fe and Al precipitates that formed on the waste concrete were amorphous and produced broad diffraction peaks in XRD analysis which were difficult to identify by XRD diffractogram curves alone. However, quantitative XRD analysis confirmed the precipitates as Al hydroxides (gibbsite and boehmite) and Fe oxyhydroxides (goethite), respectively, and quantified the ratio of $\mathrm{Al}(\mathrm{OH})_{3}$ to $\mathrm{FEOOH}$ as $40-60$. The abrupt increase in the $\mathrm{Al}$ concentration after day 190 coincided with the depletion of bicarbonate alkalinity and an abrupt decrease in $\mathrm{pH}$ from $\mathrm{pH} 6$ to $\mathrm{pH}$ 4. A negligible amount of total Fe was observed in the effluent compared with $\mathrm{Al}$ until the end of the experiment. This is because Fe continued to precipitate until $\mathrm{pH} 3.5$, whereas $\mathrm{Al}$ precipitated until the $\mathrm{pH}$ was maintained above $\mathrm{pH} 4$. The column experiment was ceased at 260 days when the effluent reached $\mathrm{pH} 4$. Therefore, it is noted that the further trend of effluent Fe concentration under an acidic condition of below $\mathrm{pH} 4$ was not investigated in this study.

The concentration of the remaining major ions $\left(\mathrm{Mg}^{2+}\right.$, $\mathrm{Na}^{+}, \mathrm{K}^{+}, \mathrm{Cl}^{-}$and $\mathrm{SO}_{4}^{2-}$ ) in the effluent and influent was relatively constant throughout the entire experiment (Fig. 8) indicating that they were not involved in the acid neutralisation process. However, slightly higher concentration of these ions in the effluent compared to the

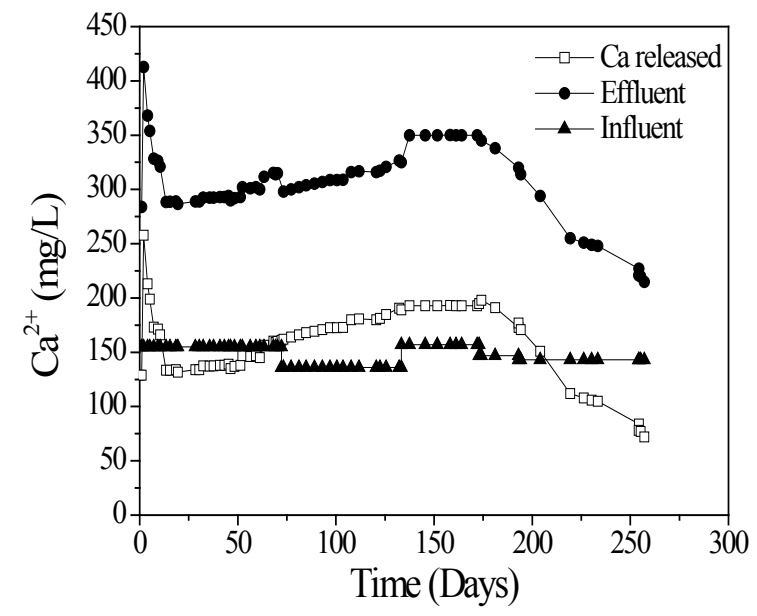

Fig. 5. Aqueous Ca concentration in the effluent and influent and the Ca released from the waste concrete as a function of time.

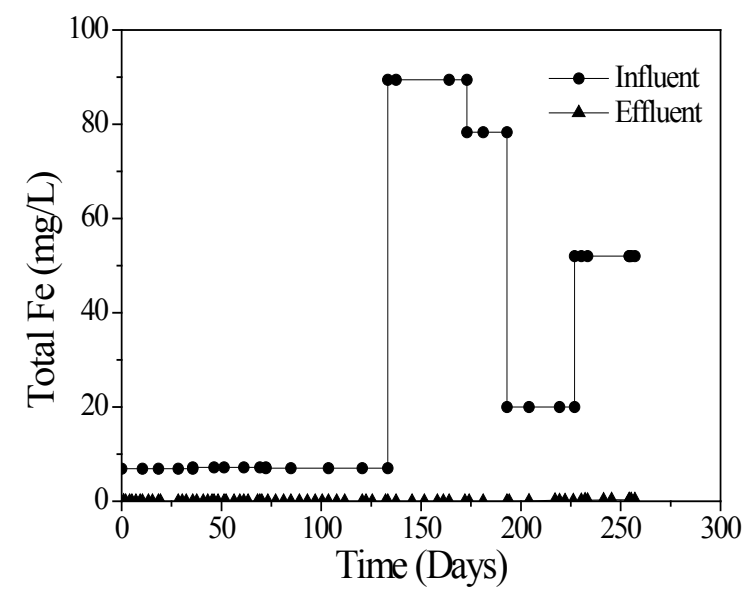

Fig. 6. Aqueous total Fe concentration in the effluent and influent as a function of time.

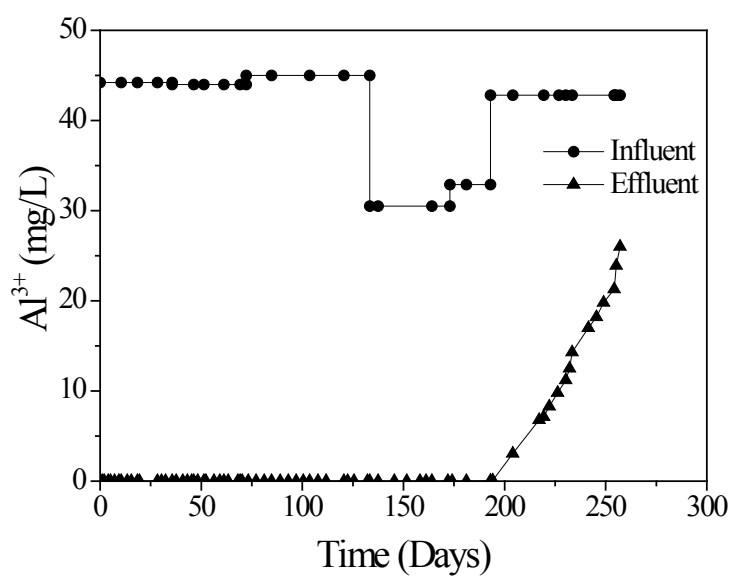

Fig. 7. Aqueous Al concentration in the effluent and influent as a function of time. 


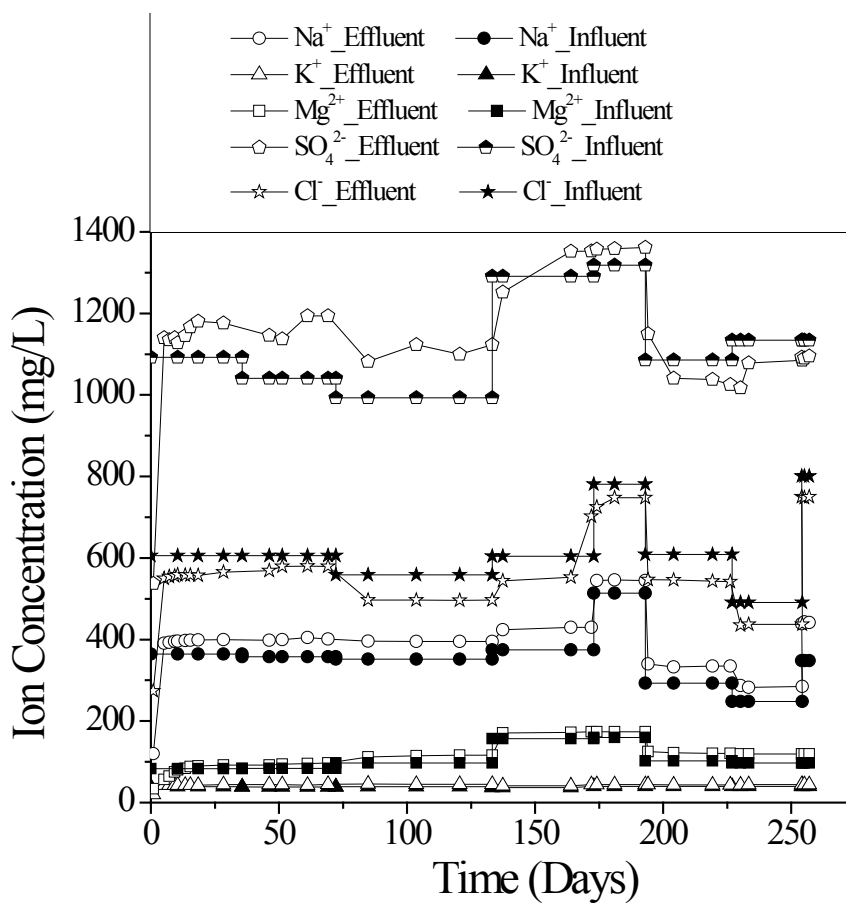

Fig. 8. Concentration of the remaining ions in the effluent and influent as a function of time.

influent was attributed to leaching of the minerals from the concrete. Similar to our study, Indraratna et al. [14] reported that these elements are almost inert in the acid neutralisation of the PRB with an evidence of no significant changes in the remaining ions up-gradient, inside and down-gradient of the pilot PRB in ASS. Although Ca was released from the concrete and there was a high concentration of $\mathrm{SO}_{4}^{2-}$, gypsum precipitation, as observed by other researchers in acid mine drainage treatment (see for example Komnitsas et al. [21]), was not found in this study. This is because $\mathrm{SO}_{4}^{2-}$ concentrations were less than $2000 \mathrm{mg} / \mathrm{L}$, which is insufficient for gypsum precipitation. Regmi et al. [13] reported that waste concrete contained a negligible amount of heavy metals. Indraratna et al. [20] also demonstrated that heavy metals leached from PRB filled with recycled concrete for treating acidic groundwater in ASS was negligible. Therefore, release of heavy metals from the waste concrete was not considered in this study.

\subsection{Efficiency of reactive material}

Armouring of the concrete and porosity reduction by accumulation of Fe and $\mathrm{Al}$ precipitates in the void spaces was observed throughout the length of the column during the experiment. Significant changes in piezometric head did not occur because of the use of larger concrete particles. This minimised the threat of chemical clogging, one of the expected failure mechanism in reducing the longevity of the PRBs technology, reported by many researchers [22,23]. However, armouring on the surface of the concrete by Fe and $\mathrm{Al}$ precipitates could result in a decrease in the rate of mineral dissolution and subsequent exhaustion of the ANC of the concrete. The 147th day was selected as a baseline for evaluating the efficiency of the concrete's ANC based on $240 \mathrm{~L}$ treated acidic groundwater over a $\mathrm{pH}$ of 7, complete removal of $\mathrm{Fe}$ and $\mathrm{Al}$ and considerable alkalinity within the column. The average acidity of the field groundwater was $365 \mathrm{mg} / \mathrm{L}$ as $\mathrm{CaCO}_{3}$. The average ANC value of the concrete was $145 \mathrm{mg} / \mathrm{g}$ equivalent $\mathrm{CaCO}_{3}$ [14]. The concrete used in the column (1206 g) had the capacity to neutralise $483.2 \mathrm{~L}$ of acidic groundwater to $\mathrm{pH} 7$. This indicates a nearly $50 \%$ loss in the concrete's efficiency by armouring although it had the capacity to neutralise almost the same volume of acidic water treated.

Longevity of the reactive material for treating acidic groundwater from ASS therefore depends on two major factors: (a) fluctuation of the groundwater acidity due to changes in pyrite oxidation rate in shallow depth of soil and (b) the amount of $\mathrm{Al}$ and Fe leached to the groundwater. However, continuous neutralisation acidic water collected under variable field conditions and complete removal of the toxic $\mathrm{Al}$ and Fe under high flow rate in the laboratory controlled environment illustrates that the waste concrete is a suitable reactive material for treating contaminated groundwater from ASS.

\section{Conclusions}

This paper evaluates the efficiency of waste concrete for remediating contaminated groundwater generated from acid sulphate soils. A laboratory column test confirmed the suitability of the material in decontaminating acidic leachates loaded with high concentrations of hazardous metal ions such as Fe and Al. The maintenance of near neutral $\mathrm{pH}$ and effective removal of Fe and $\mathrm{Al}$ was realised when pozzolanic reactions took place between the Ca-bearing minerals of the concrete and acidic groundwater and generated alkalinity within the column. Continuous removal of these dissolved metals was caused by mineral precipitation on the reactive material surface at high $\mathrm{pH}$ and led to a longer-term decline in reactivity. Excessive armouring reduced the life of the material by nearly half. However, the possibility of temporal clogging, unlike other fine reactive media used in commercial PRBs, was reduced due to the use of larger concrete particle sizes.

Despite a reduction of material efficiency due to armouring, performance of the waste concrete was high and sustainable for an extended period under controlled laboratory conditions. In conclusion, a long-term column experiment for treating ASS affected groundwater has shown the successful application of waste concrete for the remediation of groundwater in ASS terrain under varying conditions. In addition, it is recommended that the 
material used in the PRB should not be left in the ground when the efficiency of the PRB system drops because resolubilisation of previously formed unstable precipitates under acidic conditions will worsen the groundwater quality significantly.

\section{Acknowledgements}

The authors would like to acknowledge Associate Prof. Dr. Brian Jones from Faculty of Environmental Earth Science, UOW for his assistance in mineralogical analysis. We would like to thank Bob Rowlan and Jose Abrantes from UOW and Glenys Lugg from Manildra for their assistance during this study. Technical comments and suggestions from Dr. Alexandra Golab are highly appreciated.

\section{References}

[1] I. White, M.D. Melville, B.P. Wilson and J. Sammut, Reducing acidic discharges from coastal wetlands in eastern Australia, Wetlands Ecol. Manage., 5 (1997) 55-72.

[2] P.H. Walker, A Reconnaissance of Soils in the Kempsey District, NSW, CSIRO Soils and Land Use Series No. 44, in, Melbourne, 1963.

[3] D. Dent, Reclamation of acid sulphate soils, Adv. Soil Sci., 17 (1992) 79-122.

[4] C. Lin, M.D. Melville and S. Hafer, Acid sulphate soils-landscape relationships in an undrained, tide-dominated estuarine floodplain, Eastern Australia, Catena, 24 (1995) 177-194.

[5] J. Sammut, I. White and M. Melville, Acidification of an estruarine tributary in eastern Australia due to drainage of acid sulfate soils, Mar. Freshwater Res., 47 (1996) 669-684

[6] W. Glamore and B. Indraratna, A two-stage decision support tool for restoring tidal flows to flood mitigation drains affected by acid sulfate soil: case study of Broughton Creek floodplain, New South Wales, Australia Aust. J. Soil Res., 42 (2004) 639-648.

[7] B. Indraratna, A. Golab, W. Glamore and B. Blunden, Acid sulphate soil remediation techniques on the Shoalhaven River Floodplain, Australia, Q.J. Eng. Geol. Hydroge., 38 (2005) 129-142.

[8] R.T. Wilkin, R.W. Puls and G.W. Sewell, Long-term performance of permeable reactive barriers using zero-valent iron: geochemical and microbiological effects, Ground Water, 41 (2003) 493-503.

[9] B. Gu, D.B. Watson, D.H. Phillips and L. Liang, Biogeochemical, mineralogical, and hydrological characteristics of an iron reactive barrier used for treatment of uranium and nitrate, in: D.L. Naftz, S.J. Morrison, J.A. Davis and C.C. Fuller, eds., Groundwater Re- mediation of Trace Metals, Radionuclides, and Nutrients, with Permeable Reactive Barriers, Academic Press, San Francisco, 2002, pp. 305-342.

[10] R.D. Ludwig, R.G. McGregor, D.W. Blowes, S.G. Benner and K. Mountjoy, A permeable reactive barrier for treatment of heavy metals, Ground Water, 40 (2002) 59-66.

[11] K.R. Waybrant, C.J. Ptacek and D.W. Blowes, Treatment of mine drainage using permeable reactive barriers: column experiments, Environ. Sci. Technol., 36 (2002) 1349-1356.

[12] R. Desmier, D.T. Waite, M. Melville and B. Macdonald, Applicability of acid mine draining treatment techniques to amelioration of acid sulfate soil discharge, in: R. Bush, ed., Proc. 5th International Acid Sulfate Soils Conference - Sustainable Management of Acid Sulfate Soils, Tweed Heads, Australia, 2002, pp. 121-122.

[13] G. Regmi, B. Indraratna and L.D. Nghiem, Long-term Performance of a permeable reactive barrier in acid sulphate soil terrain, Water Air Soil Pollut. Focus, 9 (2009) 409-419.

[14] B. Indraratna, G. Regmi, L. Nghiem and A. Golab, Performance of a permeable reactive barrier (PRB) for the remediation of groundwater in acid sulphate soil terrain, J. Geotech. Geoenviron. Eng., ASCE, 136 (2010) 897-906.

[15] APHA, Standard Methods for the Examination of Water and Wastewater, 20th ed., American Public Health Association, Washington, 1998.

[16] C.R. Ahern, A. McElnea and L. Sullivan, Acid Sulfate Soils Laboratory Methods Guidelines, in, Queensland Department of Natural Resources, Mines and Energy, Indooroopilly, Queensland, Australia, 2004.

[17] E. Álvarez-Ayuso and H.W. Nugteren, Synthesis of ettringite: a way to deal with the acid wastewaters of aluminium anodising industry, Wat. Res., 39 (2005) 65-72.

[18] A.N. Golab, M.A. Peterson and B. Indraratna, Selection of potential reactive materials for a permeable reactive barrier for remediating acidic groundwater in acid sulphate soil terrains, Q.J. Eng. Geol. Hydroge., 39 (2006) 209-223.

[19] J. Jurjovec, C.J. Ptacek and D.W. Blowes, Acid neutralization mechanisms and metal release in mine tailings: a laboratory column experiment, Geochim. Cosmochim. Acta, 66 (2002) 1511-1523.

[20] G. Regmi, B. Indraratna, L.D. Nghiem, A.N. Golab and B. Guruprasad, Treatment of acid groundwater in acid sulphate soil terrain using recycled concrete: Column experiments, J. Environ. Eng., ASCE, in press, June 2011 issue, doi:1061/(ASCE)EE.19437870.0000331 (2010).

[21] K. Komnitsas, G. Bartzas and I. Paspaliaris, Efficiency of limestone and red mud barriers: laboratory column studies, Miner. Eng., 17 (2004) 183-194.

[22] L. Li, C.H. Benson and E.M. Lawson, Impact of mineral fouling on hydraulic behavior of permeable reactive barriers, Ground Water, 43 (2005) 582-596.

[23] L. Li and C.H. Benson, Evaluation of five strategies to limit the impact of fouling in permeable reactive barriers, J. Hazard. Mater., 181 (2010) 170-180. 